\title{
CONSTRUCTION OF THE VOLGA-DON RAILWAY (1859-1862)
}

\author{
Andrey V. Lunochkin \\ Volgograd State University, Volgograd, Russian Federation
}

\begin{abstract}
The article deals with the problems associated with the construction of the Volga-Don railway which connected Tsaritsyn and Kalach-on-Don in 1862. It became one of the first to be built in Russia during the so-called 'Railway boom' of the 1860s. The joint-stock company of the Volga-Don railway and the shipping company in the Don and the Sea of Azov was established on July 19, 1858. Its founders were entrepreneur N.A. Novoselsky, engineer P.P. Melnikov one of the builders of the St. Petersburg-Moscow railway, and millionaire V.A. Kokorev. The capital of the company amounted to 8 million rubles in the shares of 500 rubles each. The shareholders were mainly represented by high-ranking military and civil officials, including Finance Minister A. Knyazhevich. The works on the construction started on May 8, 1859. Construction took place in a situation of demonstrative publicity and attracted much public attention. Despite this, the working and living conditions of the workers were unbearable, which led to illness and high mortality. Complaints of workers were suppressed by force, including corporal punishment. In the summer of 1860 , mass shoots took place at the construction site, weapons were used for their suppression. The scandal was publicized in the press and became the reason for the adoption of the first rules in Russia on hiring workers. The construction of the Volga-Don railway was finished in the spring of 1862, and the regular railway traffic was launched on April 27. The newly constructed railway gave a hefty boost to the economic development of Tsaritsyn and started the industrial epoch in the South of Russia.

Key words: the Volga, the Don, construction of railways, Russia, the 1850-1860s, joint stock companies, P.P. Melnikov, V.A. Kokorev.

Citation. Lunochkin A.V. Construction of the Volga-Don Railway (1859-1862). Vestnik Volgogradskogo gosudarstvennogo universiteta. Seriya 4, Istoriya. Regionovedenie. Mezhdunarodnye otnosheniya [Science Journal of Volgograd State University. History. Area Studies. International Relations], 2018, vol. 23, no. 2, pp. 8999. (in Russian). DOI: https://doi.org/10.15688/jvolsu4.2018.2.7
\end{abstract}

\section{СТРОИТЕЛЬСТВО ВОЛГО-ДОНСКОЙ ЖЕЛЕЗНОЙ ДОРОГИ (1859-1862)}

\author{
Андрей Валентинович Луночкин \\ Волгоградский государственный университет, г. Волгоград, Российская Федерация
}

\footnotetext{
Аннотация. В статье рассматриваются проблемы, связанные со строительством Волго-Донской железной дороги, соединившей Царицын и Калач-на-Дону. Она стала одной из первых, возведенных в России во время так называемого «железнодорожного бума» 1860-х годов. В деятельности акционерного общества, строившего дорогу, отразились все характерные черты начального этапа становления российского капитализма - от большого количества высокопоставленных лиц среди акционеров и учредителей (инженер-путеец П.П. Мельников, миллионерВ.А. Кокорев) до бесправного положения и жестокой эксплуатации рабочих. Строительство проходило в обстановке демон글 стративной гласности и привлекало большое внимание общественности. Волго-Донская железная дорога дала мощ๓ं ный толчок экономическому развитию Царицына и открыла промышленную эпоху на Юге России.

Ключевые слова: Волга, Дон, строительство железных дорог, Россия, 50-60-е гг. ХІХ в., акционерные общества, П.П. Мельников, В.А. Кокорев.

Цитирование. Луночкин А. В. Строительство Волго-Донской железной дороги (1859-1862) // Вестник Волгоградского государственного университета. Серия 4, История. Регионоведение. Международные отношения. - 2018. - Т. 23, № 2. - C. 89-99. - DOI: https://doi.org/10.15688/jvolsu4.2018.2.7
} 
После неудачной Крымской войны, показавшей всю пагубность отсутствия надежных путей сообщения, в России началось ускоренное строительство железных дорог, в основном частных. Одним из первоочередных направлений стал узкий, всего около 60 км, перешеек между Волгой и Доном в районе Царицына, с древности получивший название Переволоки. Здесь проходил основной поток грузов из центра России в Приазовье и Северный Кавказ, достигавший нескольких миллионов пудов в год [8, с. 69-75]. Строившаяся в 1859-1862 гг. Волго-Донская железная дорога стала первой на всем Юге России, открыв тут промышленную эру.

Образование акционерного общества и строительство Волго-Донской железной дороги происходили в обстановке общественного подъема в России конца 1850-х годов. Общественное мнение становилось серьезной силой, которую надо было привлекать на свою сторону, и учредители компании это понимали. Новообразованная компания вела дела с небывалой в русском коммерческом мире открытостью. Благодаря модной в это время «гласности» исследователь имеет в своем распоряжении довольно большой массив источников, опубликованных в периодической печати, прежде всего в газетах «Журнал для акционеров (1857-1860) и «Акционер» (1860-1863), официальных изданиях. Это списки акционеров, подробные отчеты о дебатах на собраниях акционеров, ежегодные финансовые отчеты общества, корреспонденции о ходе строительных работ $[1 ; 2 ; 10-15 ; 20 ; 22]$. Громкий резонанс в прессе получили также события вокруг волнений рабочих на строительстве железной дороги в 1860 году [5]. Документы официального расследования этих волнений опубликованы в сборнике «Рабочее движение в России» $[6 ; 19]$. Большой массив неопубликованных данных о ходе строительства содержит делопроизводственная документация Департамента железнодорожных дел Главного управления путей сообщения и публичных зданий $[16 ; 17]$ и канцелярии Донского войскового наказного атамана [18].

Несмотря на большое народнохозяйственное значение и пионерскую роль Волго-Донской железной дороги для Юга России, история ее строительства до сих пор не становилась предметом специального изучения. В поле зрения исследователей попали лишь волнения рабочих в 1860 году [21]. В общих трудах по истории железнодорожного дела России ВолгоДонская дорога, как правило, только упоминается в числе прочих, построенных на рубеже 1850-1860-х годов [7, с. 88]. Видимо, из-за своей малой протяженности и удаленности от центра страны Волго-Донская железная дорога оказалась для историков в тени созданной в это время крупнейшей компании - Главного общества российских железных дорог.

Предложения о постройке железной дороги между Волгой и Доном стали приходить в Главное управление путей сообщений и публичных зданий (далее - ГУПС) еще в ходе Крымской войны, с февраля 1856 года. Всего за этот год на эту тему поступило четыре предложения от разных лиц, но только одно увенчалось успехом. Коллежскому секретарю А.А. Деревицкому и графу Н.И. Мусину-Пушкину 21 июня 1856 г. было разрешено произвести изыскания по трассе будущей дороги за свой счет [16, л. 60]. Общее руководство изысканиями было поручено выдающемуся инженеру, одному из главных строителей Петербурго-Московской железной дороги П.П. Мельникову. На трассу будущей дороги был послан начальник 9-й дистанции II отделения Николаевской железной дороги инженер-капитан Ф.К. Хржановский, в помощь ему командировались также прапорщик и два архитекторских помощника. Всего на производство полевых изысканий и составление проекта железной дороги А.А. Деревицкий и Н.И. МусинПушкин выделили 8 тысяч рублей.

В феврале 1857 г. проект дороги и смета были готовы. Экспедиция П.П. Мельникова и Ф.К. Хржановского отвергла направление от Дубовки до станицы Качалинской, по которому уже несколько десятилетий шел основной поток грузов и где в 1846 г. уже была построена конно-железная дорога, не оправдавшая сделанных затрат. Выбор был сделан в пользу направления от Царицына на хутор Калач, поскольку здесь благодаря рельефу местности требовалось гораздо меньше земляных работ. Решение проблемы крутого подъема от Волги предусматривало два варианта. По первому - устраивались две наклонные плоскости с постоянной паровой машиной, которая мог- 
ла бы втаскивать вагоны на водораздел наподобие фуникулера. По второму - под хребтом строился туннель длиной 1 465,2 саженей. Общая стоимость дороги по смете составила 5714260 р. в случае строительства туннеля, или 3318730 p. - в случае варианта с наклонной плоскостью [16, л. 13-16].

Ознакомившись с проектом, А.А. Деревицкий и Н.И. Мусин-Пушкин вскоре отказались от своего намерения и передали права на проект новой компании из трех учредителей коллежского советника Н.А. Новосельского, известного миллионера-откупщика В.А. Кокорева и автора проекта дороги П.П. Мельникова. Эти кандидатуры не встретили возражений в правительстве, и 19 июля 1858 г. Александр II утвердил устав акционерного общества Волго-Донской железной дороги и пароходства по Дону и Азовскому морю. Общество получило большие привилегии - освобождение на 4 года от таможенных пошлин на ввозимые из-за границы рельсы, паровозы, вагоны и другие принадлежности, никакие другие компании не могли строить подобную дорогу в 150-верстной полосе на протяжении 20 лет. Капитал общества определялся в 8000000 р., для чего разрешалось выпустить 16 тыс. акций по 500 рублей. Ввиду значительной стоимости акций (500 руб.) было решено пойти навстречу желающим стать акционерами и выплату разделить на 10 взносов в равных долях. Таким образом, первоначальный взнос составлял всего 50 рублей [4, с. 43-51].

Пока начиналась подписка на акции, в августе 1858 г. П.П. Мельников с четырьмя инженерами снова отправился в район дороги для дополнительных изысканий. Их результатом стали существенные изменения в первоначальном проекте. Самым главным из них можно считать отказ от дорогостоящих наклонных плоскостей или туннеля. П.П. Мельников провел трассу по левому берегу р. Ельшанки, где уклон был не столь большой, и можно было обойтись лишь дополнительным паровозом. В середине дистанции трасса прошла по долине р. Карповки. Промежуточные станции впервые получили свои названия Крутая, Карповская и Кривомузгинская. Вся длина дороги составила теперь 72 версты 298 сажен, что было на 2 версты короче первоначального варианта. На линии предстояло переместить 120000 куб. сажен грунта, построить 7 железных мостов на каменных устоях и уложить в балках 3 каменные и 7 чугунных водопропускных труб [16, л. 82-88].

Подписная кампания на акции постепенно приносила результаты. Судя по опубликованным в прессе спискам, среди акционеров преобладали военные и гражданские чиновники и члены их семей. В их составе оказалось довольно много высокопоставленных лиц, включая и министра финансов А.М. Княжевича $[9$, с. 108-112].

Весной 1859 г. работы по постройке железной дороги вступили в практическую фазу. В Царицын для руководства стройкой были командированы инженер-подполковник Ф.А. Поземковский и три инженера-путейца. Чертежной частью заведовал архитекторский помощник М.Ю. Арнольд, участвовавший еще в изыскательской экспедиции 1856 года.

Работы по устройству земляного полотна были сданы известному уже в строительном деле подрядчику, вытегрскому купцу 1-й гильдии Г.В. Гладину, по 3 р. 10 к. за куб. сажень. Из всего объема в 160000 куб. саженей он должен был сделать в 1859 г. половину, а закончить всю работу к июлю 1860 года [11]. Для производства этих работ подрядчиком было завербовано около 2000 рабочих, преимущественно крестьян северных губерний Вологодской, Тверской и Смоленской. В апреле караван барж со строителями отправился из Нижнего Новгорода и 29 апреля достиг Царицына. Основной лагерь строителей разместился примерно на середине дистанции, вблизи будущей станции Карповской. Немаловажным обстоятельством в пользу этого места стало наличие невысыхающей летом речки. Первая лопата грунта была вынута 8 мая 1859 г., и эту дату следует считать началом строительства дороги [16, л. 165].

Судя по публичным речам и выступлениям в прессе руководителей акционерного общества, строительство Волго-Донской железной дороги должно было стать примером нового прогрессивного ведения дела. Однако все оказалось совсем не так. Занятый в это время другими крупными стройками, Г.В. Гладин поручил производство работ своему родственнику И. Головкину, по отзыву расследо- 
вавшего события чиновника, человеку «самой скверной нравственности» [6, с. 884]. На линии будущей дороги для рабочих не было приготовлено ни помещений, ни кухонь и лазаретов, ни даже запасов продовольствия. Рабочие голодали практически всю дорогу от Нижнего Новгорода до Царицына, затем должны были сами копать для себя землянки. Скудный царицынский рынок не мог предоставить достаточного количества продуктов для пропитания такого большого числа людей.

Положение не менялось и в дальнейшем. Неизбежным результатом таких бытовых условий стали болезни. Уже в начале июня на стройке болело цингой и лихорадкой до 200 человек. Положение еще более усугубилось, когда началась обычная для этой местности летняя жара. Из-за вопиюще антисанитарных условий с конца июня на стройке развились холера и тиф, между тем на всю стройку имелся один врач и один фельдшер, почти не располагавшие медикаментами. Среди рабочих начался ропот, но И. Головкин видел выход только в силовых мерах. Для предотвращения недовольства и побегов были наняты казаки, применялись телесные наказания.

К середине июля на стройке создалась взрывоопасная ситуация. Очевидно, именно она стала причиной приезда 11 июля в Царицын с инспекцией П.П. Мельникова. В официальном рапорте он не упомянул о имевшихся проблемах, отметив в целом успешный ход работ - к этому времени было произведено 21000 куб. сажен земляных работ [16, л. 165]. Видимо, авторитет П.П. Мельникова, к тому времени уже ставшего генерал-лейтенантом, позволил добиться некоторого улучшения положения рабочих. Их стали лучше кормить, были устроены и снабжены медикаментами лазареты [6, с. 885]. Однако тиф, лихорадка, поносы и холера все усиливались. По рапорту сыскного начальника 2-го Донского округа, к середине июля на стройке умерло 30 рабочих, и около 100 находились в лазарете. Распорядители просили донские власти прислать трех фельдшеров, но их здесь просто не имелось. По распоряжению войскового атамана на строительство были отправлены окружной врач и старший фельдшер из Качалинской станицы [18, л. 63, 70].
В августе в двух лазаретах - Карповском и Кривомузгинском, работали уже два врача и четыре фельдшера. Однако и в сентябре болело даже по официальным данным 250 человек [11]. На самом деле их было, очевидно, еще больше. Главной причиной повальных болезней на стройке следует считать полное пренебрежение распорядителей к бытовому обустройству рабочих. Те жили в примитивных шалашах и землянках, сооруженных самостоятельно, никаких правил санитарии и гигиены не соблюдалось, к тому же жаркая погода приводила к скорой порче пищи. Правление общества сваливало всю вину на самих рабочих за «неумеренное употребление разных овощей, изобильных и дешевых в краю» [11]. Впрочем, определенная доля истины находилась и в этом неуклюжем объяснении. Выросшие на Верхней Волге рабочие вряд ли знали меру в потреблении степных арбузов, дынь, тыкв и прочих даров юга. Наконец, не привыкшие к здешнему солнцу люди просто плохо переносили тяжелый труд на безжалостной жаре. Назначенные В.А. Кокоревым за свой счет для рабочих, занятых на территории Царицынского уезда, ежедневные винные порции помогали плохо, но развили между рабочими пьянство [6, с. 885].

Приехавший в Царицын в сентябре 1859 г. главный подрядчик Г.В. Гладин застал здесь такое состояние дел, что вынужден был прекратить работы ранее предположенного срока. Вместо 1 ноября рабочие были распущены 1 октября. Итог года оказался печальным. На протяжении сезона 1859 г. на стройке по официальным данным умерло около 500 человек, бежало более 300 рабочих [6, c. 886]. Оставшиеся ушли со стройки изнуренными и озлобленными. Неудивительно, что запланированный объем земляных работ был выполнен менее чем наполовину - 52 552,4 куб. саженей. Обществу эти работы обошлись в 140960 р. 29 к. Из двух тысяч рабочих, прибывших на стройку весной, остались зимовать в Царицыне только 200 человек, тем не менее правление по-прежнему доверяло Г.В. Гладину и выдало ему задаток на проведение земляных работ в следующем году в размере 105691 р. 52 коп. [15].

Постройки жилых и станционных зданий и каменных частей мостовых сооружений 
были сданы саратовскому 1-й гильдии купцу В.В. Гудкову, но за 1859 г. удалось сделать очень немного. На возведение постоянных и временных построек было затрачено 25038 р. 06 к. [15]. Основные усилия в этом году были направлены на заготовку материалов и оборудования. Как отмечалось в годовом отчете, много средств общество затратило на заказы по изготовлению подвижного состава, рельсов и принадлежностей для путевого хозяйства.

Так, в Петербурге на Александровском заводе у заводчиков Уайнанс, Гаррисон и Уайнанс было заказано 8 паровозов по 17500 р. и 240 товарных вагонов по 910 р. В 1859 г. по этим заказам было уплачено 239729 р. 39 к., или $2 / 3$ от стоимости всего контракта. Результатом длительной командировки в Европу Д.Н. Журавского стало заключение нескольких значительных контрактов. В Англии на заводе Геста и Ко было заказано 6450 т рельсов (уплачено в 1859 г. 24282 р. 47 к.), на заводе Уарда - 400 т рельсов большей прочности для станций и подъемов (уплачено 4668 р. 59 к.). Во Франции на заводе Гуэна и Ко были заказаны детали для железных мостов с доставкой их в Керчь (уплачено 10756 р. 17 к.), на заводе Кайля - поворотные круги, стрелки и прочие принадлежности на 109400 р. (уплачено 33095 р. 92 к.), а на заводе Гаргана и Ко - 10 пассажирских и 6 багажных вагонов с доставкой в Таганрог на 39550 p. (уплачено 7896 р. 68 к.). Для устройства телеграфа у механика Тиллера были приобретены 10 аппаратов Морзе и проволока на 9816 p. 74 к. (уплачено полностью) [15].

Как всегда, значительными были административные расходы - всего 89519 р. 27 к. Акционерам было выплачено 25887 р. 47 к. процентов на вложенный капитал, относящийся к железной дороге. Самой скромной, несмотря на повальные болезни, стала сумма, отпущенная на устройство лазаретов и пользование больных - 7804 р. 37 к. Всего же вместе с предварительными расходами 1858 г. к 1 января 1860 г. на нужды железной дороги было потрачено 926962 р. 53 к. [15].

Вместе с затратами на пароходство, устройство лесоразработок и угольных копей общие расходы акционерной компании в 1860 г. составили 1758793 р. 11 к. Поступления же от первых трех взносов (по 150 р.) на акции составили 2396550 р. [15]. Таким образом, из 16000 акций было реализовано 15977 шт., и общество могло создать уставный капитал полностью. Вместе с тем произведенные расходы составили почти четверть всего капитала, а сделано было, особенно по строительству железной дороги, очень мало. Это обстоятельство стало серьезным поводом к беспокойству рядовых акционеров о судьбе всего предприятия. Несмотря на то что прошло три взноса и в каждое свидетельство на акцию было реально вложено по 150 р., в марте 1860 г. на петербургской бирже они продавались наполовину дешевле - по 75 р. [22]. Чтобы подогреть падающий интерес к вложению денег в акции общества, на общем собрании 23 декабря 1859 г. В.А. Кокорев выступил с заманчивой инициативой. Он гарантировал собственными средствами выплату твердого дохода по акциям после открытия дороги в первые 5 лет по 5,5\%, во вторые 5 лет - по $6 \%$, в третьи 5 лет - по 6,5 \% в год [12]. Впрочем, это обещание так и не было выполнено.

На следующий 1860 г. было намечено израсходовать 3462000 р., из них на железную дорогу - 2740000 р. [12]. Для покрытия этих расходов было назначено еще три взноса по 50 р. на акцию. Эти цифры показывают, что правление общества считало 1860 г. решающим в строительстве железной дороги. Основные работы должны были быть произведены именно в этом году. Так, на устройство земляного полотна было ассигновано 457000 р. из общего объема в 653632 р., на укладку верхнего строения пути - 285000 из 379 000. В 1860 г. планировалось полностью закончить земляные работы на главном пути и уложить там рельсы. Таким образом, на 1861 г. оставалось только обустроить пристани и разъезды. На возведение станционных, мостовых и дорожных сооружений выделялось 806000 из общей суммы 1292000 р., значительные выплаты предстояли также при окончательном расчете за сделанные в прошлом году заказы [12].

В феврале 1860 г. управляющий царицынской конторой инженер Ф.А. Поземковский отказался от службы в обществе, и на это место был назначен еще один подчиненный П.П. Мельникова по путейскому ведомству инженер-полковник В.С. Семичев. Несмотря 
на явную неудачу в прошлом году, главным подрядчиком по строительству железной дороги и в 1860 г. остался Г.В. Гладин. Он должен был обеспечить не только возведение насыпи и выемок на линии, но принял на себя также поставку и укладку 150000 шпал, с обязательством одну треть поставить в июле, а оставшуюся часть - в августе. Также он должен был поставить и балласт на нижний слой из песка по 9 р. за куб. сажень на всем протяжении дороги, кроме последних 8 верст у Дона, где грунт был песчаным. Он же выступал и как организатор укладки рельсов по 650 р. за версту с обязательством закончить работу к декабрю 1860 года. Наконец, Г.В. Гладин обязался также устроить шпунтовую перемычку на берегу Волги для каменной набережной Волжской станции ценой 55 p. за сажень [11].

Земляные работы на трассе дороги начались в 1860 г. с 29 марта. Для увеличения темпов строительства подрядчик нанял в этом году намного больше рабочих. В дополнение к 200 землекопам из числа первой партии, перезимовавшим в Царицыне, были завербованы еще 2500 человек, преимущественно из Воронежской, Тамбовской и Рязанской губерний. В начале апреля на работах уже находилось 1179 человек [15]. Лечебную часть теперь взяло на себя общество. В Царицыне и Калаче были устроены лазареты, на линии имелось два врача и 14 фельдшеров. Однако в остальном положение изменилось мало. Прибывшие рабочие были распределены на 10 пунктах - 4 в пределах Царицынского уезда и 6 в Земле Войска Донского. Несмотря на прошлогодний печальный опыт, отношение распорядителя работ И. Головкина к делу осталось таким же. Он снова делал ставку не на хорошие условия труда и быта, а на грубую силу. В результате летом 1860 г. на строительстве произошли события, получившие широкий резонанс на всю страну [21].

С самого начала рабочие проявляли недовольство скудной пищей и непосильными нормами выработки, но на все жалобы и просьбы о расчете подрядчик отвечал угрозами, а наиболее активных отправлял на порку в полицию. Результатом стали почти ежедневные побеги рабочих [6, с. 889]. Так, 23 мая со стройки ушли сразу 204 человека, 24 мая в
Царицыне было выпорото 15 жалобщиков, получивших от 75 до 150 ударов. 26 мая солдаты местной инвалидной команды по приказу царицынского исправника открыли огонь по очередной партии беглецов, при этом один рабочий был смертельно ранен. Побеги продолжались и далее. За период с 28 мая по 19 июня стройку покинул 161 человек с царицынского участка и 40 человек из пределов Войска Донского. Всего же в апреле - августе 1860 г. со стройки ушло 1046 рабочих, из них 901 - с Царицынского участка [6, с. 899].

События на стройке получили широкую огласку. Н.А. Добролюбов выступил по этому поводу в журнале «Современник» с резкой статьей «Опыт отучения людей от пищи», где обвинил в случившемся руководство акционерного общества и лично В.А. Кокорева: «Благоразумные распоряжения, произведшие в целой массе рабочих людей болезни и смертность, совершились в обществе Волго-Донской железной дороги, которого г. Кокорев был учредителем, и в распоряжениях этих он признает себя значительно виновным» [5, с. 186]. По личному повелению Александра II для разбирательства на место работ был направлен флигель-адъютант капитан А.М. Рылеев. Пробыв в Царицыне месяц, он представил всеподданнейший рапорт, где признал правоту рабочих: «Я убедился в истине их жалоб и тех злоупотреблениях, которые допускались при назначении им уроков» $[19$, с. 878$]$. По настоянию другого проверяющего - чиновника особых поручений при министре внутренних дел Ю.К. Арсеньева был снят с должности и предан суду один из главных виновников беспорядков царицынский городничий М.Н. Трескин. На рапорте А.М. Рылеева император наложил резолюцию с повелением Комитету министров «сообразить, какие можно принять меры, чтобы впредь подобные беспорядки не повторялись». В результате в правительстве началась работа по составлению первого документа, регламентировавшего отношения работника и работодателя - «Правил о найме рабочих для казенных, общественных или государственных работ», утвержденных 31 марта 1861 года [19, с. 882].

Скандал вокруг стройки привел к снижению спроса на акции общества Волго-Донской дороги. Впрочем, такая же проблема сто- 
яла и перед другими частными обществами. Представление их учредителей об обилии свободных капиталов в стране не соответствовало действительности. Единственной компанией, которая смогла за короткий срок собрать большие средства, стало Главное общество железных дорог, но за ним стояли известные банкирские фирмы, пользовавшиеся доверием публики. Небольшие же общества были вынуждены довольствоваться оставшимся, весьма небольшим инвестиционным потенциалом. Глава ГУПС К.В. Чевкин в докладе императору объяснял тяжелое положение обществ Волго-Донской и Московско-Ярославской дорог тем, что «ввиду переполнения рынка другими бумагами, выпущенными гарантированными железнодорожными компаниями, на акции негарантированной Волго-Донской дороги не образовалось премии и владельцы этих акций должны были продать их по весьма низкой цене» [7, с. 117]. Учитывая большое значение обеих дорог для экономического развития своих регионов, К.В. Чевкин посчитал справедливым уравнять положение их обществ с финансовыми преимуществами общества Московско-Саратовской дороги, учрежденной почти одновременно с ними, то есть предоставить им правительственную гарантию на капитал в 4,5\%. Александр II согласился с ним. По принятым 8 ноября 1860 г. дополнениям к Уставу общества стоимость одной акции уменьшалась до 400 рублей. Капитал общества таким образом при сохранении числа выпущенных акций (16 000) coставил не 8 млн руб., как предусматривалось ранее, a 6400000 рублей. На этот капитал правительство предоставляло гарантию в 4,5\% чистого дохода, но не более 288 тыс. руб. в год. Гарантия предоставлялась только после официального освидетельствования и начала эксплуатации дороги [3, с. 227-229]. Общество имело право впоследствии собрать еще 1600000 руб. или посредством займа, или через выпуск облигаций [17, л. 211].

Из-за побегов рабочих запланированный на 1860 г. объем работ был выполнен далеко не полностью. Удалось возвести всего 27 верст насыпи полотна железной дороги, что вместе с результатами прошлого года составляло меньше половины всей трассы. Укладка рельсов так и не началась, несмотря на то что необходимых для этого материалов было поставлено достаточно: 10780 шт. рельсов, 40800 шпал, 1130 куб. саж. щебня. Всего земляных работ было произведено объемом 68966 куб. саж., или в среднем по 0,225 саж. на человека в день. Были начаты работы на шести строящихся мостах - возведены опоры. На Волжской станции был вырыт котлован под здание депо, построены здание для конторы и 8 домов для служащих. На станциях Крутой и Карповской построены станционные казармы, на Донской возведены два дома для служащих, и еще для шести заложены фундаменты. По линии дороги были поставлены столбы для телеграфа и протянута проволока $[10$, с. $38-42]$.

Неутешительные итоги 1860 г. стали поводом к оживленным прениям на состоявшемся 28 февраля 1861 г. общем собрании акционеров. Некоторые из них выступили с критикой руководства общества. Так, акционер П.Ф. Гейнац нашел главную причину произошедших беспорядков и неустройств в том, что правление, постоянно находившееся в Петербурге, никак не контролировало подрядчиков. Он выступил за то, чтобы один из директоров правления постоянно находился на месте стройки [1]. Собрание избрало ревизионную комиссию для проверки состояния дел на строительстве, выводы которой были доложены общему собранию акционеров 20 мая 1861 года. Четверо из пяти членов комиссии полностью одобрили представленный правлением отчет. Лишь П.Ф. Гейнац не согласился с ним, но правление заявило, что его подсчеты ошибочны. Собрание утвердило отчет правления [13]. Было также одобрено решение правления об изменении контракта с Г.В. Гладиным, который отказывался продолжать работу, ссылаясь на понесенные крупные убытки. Пришлось прибавить ему по 80 коп. на куб. сажень земляных работ.

Основной объем работ на строительстве пришелся на 1861 год. О ходе работ в этом году источники говорят немного. Новых скандалов на стройке не было, пресса перестала обращать на нее внимание. Широко разрекламированная учредителями гласность к этому времени заметно сократилась. О произведенных в 1861 г. работах можно судить только по годовому отчету правления. Объем зем- 
ляных работ увеличился вдвое и составил 121584 куб. саженей. На всем протяжении дороги была окончена насыпь и уложены рельсы от Царицына до Калача. Полным ходом велось строительство станционных сооружений и мостов, заработала телеграфная линия. На станции Карповская был пущен кирпичный завод, обеспечивавший потребности строительства. Из Петербурга и Таганрога завозился подвижной состав, заказанный ранее. Всего на строительство железной дороги было потрачено в 1861 г. 1182774 руб. 80 коп. Заказанный ранее подвижной состав почти полностью был доставлен на место. В течение сезона на стройке трудилось до 5000 рабочих [14].

1862 г. стал годом завершения строительства. К марту все станции уже были соединены путями, производилась укладка разъездных путей. Шла отделка станционных сооружений и завершалось возведение пристаней на Волге и Дону. Стремясь быстрее начать возвращение затраченных средств, правление общества сумело добиться разрешения на перевозку товаров и людей на пробных поездах. В архивном деле Волго-Донской железной дороги упоминается, что первый такой поезд проследовал по линии 22 марта [16, л. 183]. Однако в отчете общества, опубликованном в «Саратовских губернских ведомостях», сообщалось, что первый пробный поезд с коммерческим грузом проследовал от Царицына до Калача уже 5 марта. Регулярное же движение на дороге, согласно этому отчету, открылось 27 апреля. Основным грузом стала пшеница. За первый месяц работы ее было перевезено из Царицына в Калач 471520 пудов, а всего частных товаров в обоих направлениях - 586689 пудов, и 907 пассажиров. С 27 апреля по 28 мая 1862 г. выручка составила 25752 руб. 76 коп. [20].

Итак, Волго-Донская железная дорога фактически начала свою работу в апреле 1862 года. Подробный отчет о возведенных к этому времени станционных сооружениях содержится в «Саратовских губернских ведомостях». На станции Волжской были построены: деревянный 2-этажный директорский дом, дом для помещения конторы (нижний этаж каменный, верхний деревянный), четыре 2-этажных деревянных дома со служ- бами, пять одноэтажных деревянных домов со службами, пассажирский одноэтажный деревянный дом, каменное здание паровозного депо с мастерской, водопровод. На станции Садовой были построены: одноэтажное деревянное здание станционной казармы, «водоемный дом» с водоснабжением. На станции Крутой: одноэтажный деревянный пассажирский дом, одноэтажная деревянная станционная казарма, водоподъемный дом, водоемный дом, водопровод, резервуар для воды и плотина. На станциях Карповской и Кривомузгинской - одноэтажный деревянный пассажирский дом, такая же станционная казарма, водоемный дом и водопровод. На станции Донской было возведено восемь деревянных жилых помещений, каменное паровозное депо с поворотным кругом, водопровод с колодцем и деревянный «сарай для вагонов». Пассажирское здание здесь еще не было окончено. Помимо станций, на линии дороги были построены четырнадцать деревянных казарм, десять деревянных сторожевых будок, устроены тринадцать переездов через полотно железной дороги. На пересечении балок и рек было возведено 9 путепроводов, из них один каменный, один деревянный и семь железных. Самым крупным был мост через р. Карповку - 35 саженей в пролете. На четырех станциях работали телеграфные аппараты [2].

В штате дороги числились 314 человек. Подвижной состав насчитывал 8 товарных и 2 пассажирских паровоза, 10 тендеров, 4 пассажирских вагона (в источнике они названы каретами) 1-го и 2-го класса, 2 вагона 2-го класca, 4 вагона 3-го класса, 6 багажных вагонов и 225 платформ грузоподъемностью по 600 пудов [16, л. 224-251].

Официальный акт об освидетельствовании железной дороги был подписан правительственной комиссией 15 сентября 1862 года. С этого числа должна была начаться и выплата казенной гарантии, но Александр II пошел навстречу просьбе правления и повелел начать выплату с 1 июля 1862 года [16, л. 276-297].

Волго-Донская железная дорога стала первой на всем Юге России. Несмотря на свою небольшую протяженность, она оказала значительное воздействие на экономи- 
ку региона. Благодаря удобному рельсовому пути сюда стал перемещаться основной грузопоток между Волгой и Доном, ранее проходивший между посадом Дубовкой и станицей Качалинской. Именно ей обязан началом своего торгово-промышленного развития город Царицын, ставший к началу $\mathrm{XX}$ в. крупнейшим индустриальным центром Нижней Волги.

\section{СПИСОК ЛИТЕРАТУРЫ}

1. В обществе Волго-Донской железной дороги // Акционер. - 1861. - 17 марта (№ 11).

2. Ведомость о сооружениях Волго-Донской железной дороги // Саратовские губернские ведомости. Часть неофициальная. - 1862. - 10 марта (№ 10).

3. Высочайше утвержденное положение Комитета министров, распубликованное 7 декабря: Об изменении некоторых параграфов Устава общества Волжско-Донской железной дороги и пароходства // Полное собрание законов Российской Империи. Собрание второе. - Т. XXXV. - Отд. II. - № 36301. СПб. : Тип. ІІ Отделения Собственной Е.И.В. канцелярии, 1862. - С. 227-229.

4. Высочайше утвержденный устав общества Волжско-Донской железной дороги и пароходства // Полное собрание законов Российской Империи. Собрание второе. - Т. XXXIII. - Отд. II. - № 33413. СПб. : Тип. ІІ Отделения собственной Е.И.В. канцелярии, 1860. - С. 43-51.

5. Добролюбов, Н. А. Опыт отучения людей от пищи / Н. А. Добролюбов // Современник. 1860. - № 81. - С. 186.

6. Из донесения чиновника особых поручений Ю.К. Арсеньева министру внугренних дел С.С. Ланскому // Рабочее движение в России. Т. І. 1800-1860. Волнения крепостных и вольнонаемных рабочих : сб. док. и материалов / под ред. А. М. Панкратовой. М. : Госполитиздат, 1951. - С. 883-902.

7. Кислинский, Н. А. Наша железнодорожная политика по документам архива Комитета министров / Н. А. Кислинский. - СПб. : Канцелярия Ком. министров, 1902. - Т. 1. $-343 \mathrm{c}$.

8. Луночкин, А. В. Проекты строительства железных дорог между Волгой и Доном в 30-50-х гг. XIX в. / А. В. Луночкин // Вестник Волгоградского государственного университета. Серия 4 , История. Регионоведение. Международные отношения. 2017. - Т. 22, № 2. - С. 69-75.

9. Луночкин, А. В. Служба и выгода: государственные служащие в руководстве акционерного общества Волго-Донской железной дороги (1858-
1878) / А. В. Луночкин // Власть. - 2009. - № 5. C. $108-112$.

10. О работах, произведенных на Волго-Донской железной дороге к 1 января 1861 г. // Журнал Министерства путей сообщения. - 1861. - Т. 34. C. 38-42.

11. Обзор действий Общества Волго-Донской железной дороги и пароходства // Журнал для акционеров. - 1859. - Прибавление к № 150.

12. Общее собрание акционеров Волго-Донской железной дороги, состоявшееся 23 декабря 1859 г. // Журнал для акционеров. - 1860. - Прибавление к № 156.

13. Общество Волго-Донской железной дороги и пароходства по Дону и Азовскому морю // Акционер. - 1861. - 9 июня (№ 21).

14. Отчет акционерного общества Волго-Донской железной дороги и пароходства // Саратовские губернские ведомости. Часть неофициальная. 1862. -9 июня (№ 23).

15. Отчет правления акционерного общества Волго-Донской железной дороги и пароходства по Дону и Азовскому морю // Журнал для акционеров. -1860 . - Прибавление к № 173.

16. По проекту устройства железной дороги между Волгою и Доном // Российский государственный исторический архив (РГИА). - Ф. 219.Оп. 1. - Ч. 4. - Д. 5488.

17. По просьбе правления Общества ВолгоДонской железной дороги и пароходства по Дону и Азовскому морю об отделении пароходства от железной дороги // РГИА. - Ф. 219. - Оп. 1. - Ч. 4. Д. 6646.

18. По сооружению Волго-Донской железной дороги // Государственный архив Ростовской области (ГАРО). - Ф. 46. - Оп. 1. - Д. 640.

19. Представление военного министра Н.О. Сухозанета в Комитет министров о расследовании флигель-адъютантом А.М. Рылеевым причин волнения рабочих на строительстве Волжско-Донской ж. д. // Рабочее движение в России. Т. І. 1800-1860. Волнения крепостных и вольнонаемных рабочих : сб. док. и материалов / под ред. А. М. Панкратовой. М. : Госполитиздат, 1951. - С. 877-883.

20. Сведения о количестве товаров и грузов, перевезенных по Волго-Донской железной дороге с 5 марта по 28 мая 1862 г. // Саратовские губернские ведомости. Часть неофициальная. $-1862 .-9$ июня (№23).

21. Токарев, С. Волнения рабочих на постройке железных дорог в 1859-1860 гг. / С. Токарев // Вопросы истории. - 1949. - № 1. - С. 88-98.

22. Шульц, В. Несколько слов по поводу пониженной цены на акции Волго-Донской железной дороги / В. Шульц // Журнал для акционеров. 1860. - 16 марта (№ 166). 


\section{REFERENCES}

1. V obshchestve Volgo-Donskoy zheleznoy dorogi [In the JSC of the Volga-Don Railway]. Aktsioner, 1861, no. 11 (March 17).

2. Vedomost o sooruzheniyakh Volgo-Donskoy zheleznoy dorogi [Statement on the Construction of the Volga-Don Railway]. Saratovskie gubernskie vedomosti. Chast neofitsialnaya, 1862, no. 10 (March 10).

3. Vysochayshe utverzhdennoe polozhenie Komiteta ministrov, raspublikovannoe 7 dekabrya: $\mathrm{Ob}$ izmenenii nekotorykh paragrafov Ustava obshchestva Volzhsko-Donskoy zheleznoy dorogi i parokhodstva [The Provision of the Committee of Ministers Approved by His Majesty, Published on December 7: Amending Certain Sections of the Charter of the Volga-Don Railway and Steamship Line JSC]. Polnoe sobranie zakonov Rossiyskoy Imperii. Sobranie vtoroe [Complete Collection of Laws of the Russian Empire. Collection 2]. Saint Petersburg, 1862, vol. 35, part 2, pp. 227-229.

4. Vysochayshe utverzhdennyy ustav obshchestva Volzhsko-Donskoy zheleznoy dorogi i parokhodstva [The Charter of the Volga-Don Railway and Steamship Line JSC Approved by His Majesty]. Polnoe sobranie zakonov Rossiyskoy Imperii. Sobranie vtoroe [Complete Collection of Laws of the Russian Empire. Collection 2]. Saint Petersburg, 1860, vol. 33, part 2, pp. 43-51.

5. Dobrolyubov N.A. Opyt otucheniya lyudey ot pishchi [Experience of Weaning People from Food]. Sovremennik, 1860, no. 81, p. 186.

6. Iz doneseniya chinovnika osobykh porucheniy Yu.K. Arsenyeva ministru vnutrennikh del S.S. Lanskomu [From the Report of Officer on Special Assignments Yu.K. Arsenyev to Minister of the Interior S.S. Lanskoy]. Rabochee dvizhenie v Rossii [Workers' Movement in Russia]. Moscow, Gospolitizdat Publ., 1951, vol. 1, pp. 883-902.

7. Kislinskiy N.A. Nasha zheleznodorozhnaya politika po dokumentam arkhiva Komiteta ministrov [Our Railway Policy according to the Documents of the Archive of the Committee of Ministers]. Saint Petersburg, 1902, vol. 1.343 p.

8. Lunochkin A.V. Proekty stroitelstva zheleznykh dorog mezhdu Volgoy i Donom v 30-50-kh godakh XIX v. [Projects for Construction of Railways between the Volga and the Don in 1830-1850s]. Vestnik Volgogradskogo gosudarstvennogo universiteta. Seriya 4, Istoriya. Regionovedenie. Mezhdunarodnye otnosheniya [Science Journal of Volgograd State University. History. Area Studies. International Relations], 2017, vol. 22, no. 2, pp. 69-75.

9. Lunochkin A.V. Sluzhba i vygoda: gosudarstvennye sluzhashchie $v$ rukovodstve aktsionernogo obshchestva Volgo-Donskoy zheleznoy dorogi (1858-1878) [Service and Benefits: Officials in the Directorate of the Volga-Don Railway JSC (1858-1878)]. Vlast, 2009, no. 5, pp. 108-112.

10. O rabotakh, proizvedennykh na VolgoDonskoy zheleznoy doroge $\mathrm{k} 1$ yanvarya $1861 \mathrm{~g}$. [About the Works Carried Out in the Volga-Don Railway by January 1, 1861]. Zhurnal Ministerstva putey soobshcheniya, 1861, vol. 34, pp. 38-42.

11. Obzor deystviy Obshchestva Volgo-Donskoy zheleznoy dorogi i parokhodstva [An Overview of Actions of the Volga-Don Railway and Steamship Line JSC]. Zhurnal dlya aktsionerov, 1859. (Supplement to no. 150).

12. Obshchee sobranie aktsionerov VolgoDonskoy zheleznoy dorogi, sostoyavsheesya 23 dekabrya 1859 g. [The General Meeting of Shareholders of the Volga-Don Railway of December 23, 1859]. Zhurnal dlya aktsionerov, 1860. (Supplement to no. 150).

13. Obshchestvo Volgo-Donskoy zheleznoy dorogi i parokhodstva po Donu i Azovskomu moryu [The Volga-Don Railway and Steamship Line JSC in the Don River and the Azov Sea]. Aktsioner, 1861, no. 21 (June 9).

14. Otchet aktsionernogo obshchestva VolgoDonskoy zheleznoy dorogi i parokhodstva [Report of the Volga-Don Railway and Steamship Line JSC]. Saratovskie gubernskie vedomosti. Chast neofitsialnaya, 1862, no. 23 (June 9).

15. Otchet pravleniya aktsionernogo obshchestva Volgo-Donskoy zheleznoy dorogi i parokhodstva po Donu i Azovskomu moryu [Report of the Board of the Volga-Don Railway and Steamship Line JSC in the Don River and the Azov Sea]. Zhurnal dlya aktsionerov, 1860. (Supplement to no. 173).

16. Po proektu ustroystva zheleznoy dorogi mezhdu Volgoyu i Donom [According to the Project of the Construction Railway between the Volga and the Don Rivers]. Rossiyskiy gosudarstvennyy istoricheskiy arkhiv [The Russian State Historical Archive], F. 219, Op. 1, Part 4, D. 5488.

17. Po prosbe pravleniya Obshchestva VolgoDonskoy zheleznoy dorogi i parokhodstva po Donu i Azovskomu moryu ob otdelenii parokhodstva ot zheleznoy dorogi [At the Request of the Board of the Volga-Don Railway and Steamship Line JSC in the Don River and the Azov Sea about Separation of the Steamship Line Company from the Railway Company]. Rossiyskiy gosudarstvennyy istoricheskiy arkhiv [The Russian State Historical Archive], F. 219, Op. 1, Part 4, D. 6646.

18. Po sooruzheniyu Volgo-Donskoy zheleznoy dorogi [About the Construction of the Volga-Don Railway]. Gosudarstvennyy arkhiv Rostovskoy oblasti [State Archive of the Rostov Region], F. 46, Op. 1, D. 640. 
19. Predstavlenie voennogo ministra N.O.Sukhozaneta v Komitet ministrov o rassledovanii fligel-adyutantom A.M.Ryleevym prichin volneniya rabochikh na stroitelstve Volzhsko-Donskoy zh.d. [The Representation of the Minister of War N.O.Sukhozanet to the Committee of Ministers about the investigation of Fligel-Adjutant A. M. Ryleev the Reasons for the Excitement of Workers on the Construction of the VolgaDon Railway]. Pankratova A.M., ed. Rabochee dvizhenie $v$ Rossii. T. I. 1800-1860. Volneniya krepostnykh $i$ volnonaemnykh rabochikh: Sbornik dokumentov $i$ materialov [Workers' Movement in Russia. Vol. I. 1800 1860. Agitation of Bonds and Freelance Workers. Collected Documents and Materials]. Moscow, Gospolitizdat Publ., 1951,pp. 877-883.
20. Svedeniya o kolichestve tovarov i gruzov, perevezennykh po Volgo-Donskoy zheleznoy doroge s 5 marta po 28 maya $1862 \mathrm{~g}$. [Data on Quantity of Goods and Freights Transported by the Volga-Don Railway from 5 March to 28 May 1862]. Saratovskie gubernskie vedomosti, 1862, no. 23 (June 9).

21. Tokarev S. Volneniya rabochikh na postroyke zheleznykh dorog v 1859-1860 gg. [Agitation of Workers on the Construction of Railways in 18591860], Voprosy istorii, 1949, no. 1, pp. 88-98.

22. Shulz V. Neskolko slov po povodu ponizhennoy tseny na aktsii Volgo-Donskoy zheleznoy dorogi [Few Words about the Low Stock Prices of the Volga-Don Railway]. Zhurnal dlya aktsionerov, 1860, no. 166 (March 16).

\section{Information about the Author}

Andrey V. Lunochkin, Candidate of Sciences (History), Associate Professor, Department of History of Russia, Volgograd State University, Prosp. Universitetsky, 100, 400062 Volgograd, Russian Federation, andrei.lunochkin@volsu.ru,https://orcid.org/0000-0002-7431-8906

\section{Информация об авторе}

Андрей Валентинович Луночкин, кандидат исторических наук, доцент кафедры истории России, Волгоградский государственный университет, просп. Университетский, 100, 400062 г. Волгоград, Российская Федерация, andrei.lunochkin@volsu.ru, https://orcid.org/0000-0002-7431-8906 